\title{
Practising family history: 'identity' as a category of social practice
}

\section{Wendy Bottero (University of Manchester)}

Word count 10,422

Paper last checked/updated on 08/05/2015

\begin{abstract}
Research on family history argues it performs the task of anchoring a sense of 'self' through tracing ancestral connection and cultural belonging, seeing it as a form of storied 'identity-work'. This paper draws on a small-scale qualitative study to think further on the identity-work of family history. Using practice theory, and a disaggregated notion of 'identity', it explores how the storying of family histories relates to genealogy as a leisure hobby, a form of historical research, and an information-processing activity; and examines the social organization of that narrativity, where various practical engagements render certain kinds of genealogical information more, or less, 'storyable'. Key features of 'identity-work' in family history, such as the construction of genealogy as a personal journey of discovery and identification with particular ancestors, emerge as a consequence of the procedures of family history, organized as a set of practical tasks. The paper explores 'identity-work' as a consequence of people's engagement in specific social practices which provide an internal logic to their actions, with various components of 'identity' emerging as categories of practice shaped within, and for, use. Focusing on 'identity' as something produced when we are engaged in doing other things, the paper examines how the practical organization of 'doing other things' helps produce 'identity' in particular ways.
\end{abstract}

Keywords: identity; family history; genealogy; narrative; social practice; leisure hobbies.

\section{Introduction}

The popularity of amateur genealogy in countries like Britain, Australia and America, and the increasing accessibility of online genealogical sources, has generated a mass engagement with archival research. Research into popular genealogy argues it performs the task of anchoring a sense of 'self' through tracing ancestral connections. The framing of the BBC series 'Who do you think you are?' suggests family history reworks self-identity, and genealogy is frequently framed as a quest to know 'who you are' in terms of 'where you come from' (Nash 2002: 28), with analysts noting its importance for 'identity-work' and 'selfmaking, self-exploration and self-understanding' (Kramer 2011a: 428-9). Family histories are also stories however, with the production of narrative accounts organized for practical purposes and varying audiences. This paper examines how the storying of family histories - and the identity-work it entails - is related to the practical organisation of genealogy. I do not argue against the notion of family history as 'identity-work'. 'Identity' is an over-extended concept, and it is hard to imagine any social practice which does not contribute to 'identity' in some sense. But following Brubaker's (2004: 4) disaggregation of 'identity' into 'several less congested terms', then family history clearly provides fertile ground for processes of 'self-understanding', 
'identification and categorization' and 'commonality and connectedness'. Elsewhere, I have argued for questions of 'identity' to be more firmly located within accounts of differentiated social practices (Bottero and Irwin 2003; Bottero 2010). However, if we take a 'disaggregated' notion of 'identity' seriously, then we need to consider in greater detail how the component aspects of 'identity' are carried within, and steered by, practices. In the sociology of consumption (another over-loaded concept), Warde (2005: 137) has argued that 'consumption is not itself a practice, but is, rather, a moment in almost every practice'. By extension, we can explore 'identity' as not itself a social practice, but rather a moment in almost every practice. Doing so, however, requires us to think about how the organization of specific practices helps to shape 'identity'. This paper draws on elements of social practice theory to focus on family history as an archive-based leisure activity: to explore how the tasks of family history as a social practice help shape the emphases family historians place upon the information they uncover and the accounts they construct. Adopting the stance that 'identity' is something produced when we are engaged in doing other things, the paper explores how the practical organization of 'doing other things' - here family history - helps to produce 'identity-work' in particular ways.

Why do people research their family history? Some see the rising contemporary emphasis on popular history as a reaction against rapid social change (Huyssen 1995), with acts of commemoration serving to 'anchor' unsettled modern selves. There are suggestions the rising interest in family inheritance is provoked by 'biotechnological' reconfigurations of kinship (Franklin and McKinnon 2001); that shifting discourses on ethnic 'roots' are a response to globalization and post-colonial migration (Basu 2007; Erben 1991; Tyler 2005; Nash 2003, 2008); or that family history provides ontological security in the face of social dislocation, or weakening family connection (Erben 1991; Basu 2007). Others are more agnostic as to whether interest in family history is a response to changing times, instead seeing the pursuit as part of a general 'fascination' with 'resemblances, likenesses, family "ways" and traits' (Mason 2008: 29; Kramer 2011a, b). Whether or not analysts think the interest in family history arises from concerns about 'identity', they agree the process of tracing a family tree raises such questions, and so becomes a form of 'identity-work'. But, in one sense, the reasons why people research their family history can be bracketed, since we can instead focus on family history as a collectively ordered social practice which shapes the actions, motivations and rewards of those engaged within it. There are rules and standards for any social practice that constitute the practice itself and, using practice theory, studies of consumption suggest that it is the conventions of specific practices which steer behaviour rather than individual motivation or taste. So, for example, the consumption paraphernalia of the hot rod enthusiast (modifying vehicles, attending rallies, buying magazines, memorabilia etc) follow on from the engagement in the practice of 'hot rodding' so that it is 'the fact of engagement in the practice, 
rather than any personal decision about a course of conduct, that explains the nature and process of consumption' (Warde 2005: 138).

Practice theories sees practices as central to conceptualising social life, and whilst such theories come in a dizzying variety all 'highlight the role of skills, practical understanding and non-propositional knowledge in human action' and 'partially replace...explanations of human conduct that cite mental phenomena such as reason, will, consciousness or goals' (Schatzki 2011: 1448). 'Practices' are routinised 'bundles of activity' (Schatzki 2011: 1449), 'blocks' of interdependent actions realized (and modified) in performance, but which also exist as recognizable 'entities' with associated competencies and expectations which steer performances. In the version of practice theory employed here, practices are seen as 'logically and ontologically prior to action' (Warde 2004: 5) and 'individuals feature as the carriers or hosts of a practice...a radical departure from more conventional approaches in which understandings, know-how, meanings and purposes are taken to be personal attributes' (Shove, Pantzar and Watson 2012: 7). Such a focus on how 'the conventions and the standards of practices...steer behaviour' means we must also explore how 'practices, rather than individual desires... create wants' (Warde 2005: 137). As MacIntyre has noted, by participating in a practice we take on its ends as our own, and derive intrinsic rewards ('internal goods') from following the conventions, and acquiring the know-how or skills specific to a practice. In this way, participation generates new wants, 'new ends and new conceptions of ends' (Maclntyre 1985: 273). From this perspective, once recruited into the practice of family history, it is the rules of conduct which constitute family history as family history which direct practitioners to particular kinds of desires and choices, activities and accounts. And once engaged in the pursuit, practitioners' motivations evolve with their participatory 'career' as increasing involvement creates an internal logic of motivation, value and reward. All these activities have consequences for 'identity-work', of course, but we should first see such practices as 'family history work' to fully understand their implications.

Consider the elements of family history as a social practice. 'All accounts of the past tell stories about it' (Lowenthal 1985: 229) and genealogists not only trace ancestors but also find out about their lives and generate 'storied' narratives of connection through time. If identities are 'the names we give to the different ways we are positioned by, and position ourselves within, the narratives of the past' (Hall 1990: 225 ) then the role of family history in shaping 'identity' is clear. But family history is also a leisure hobby, a form of historical research, and an information-processing activity - and these practical aspects have consequences for how narratives of family history are organized. Family historians trace a potentially large set of ancestors over a long passage of time, and using the census, registers of births, deaths and marriages, and a range of other archive sources (trade directories, wills, land registries, court and military records, newspapers) can uncover information on where ancestors lived, who they lived with, and the details of 
occupations and major life-course events. Via the digitized archives, websites, magazines, DVDs and advice manuals which have sprung up to support the 'industry', family historians research connections through space and time, tracing ancestors across borders and along the routes of slavery, industrial and colonial migration. Shove and Pantzar (2005: 44-45) stress the importance of addressing the role of 'material artifacts, infrastructures and products', with this embodied and material dimension significant in both the recruitment to, and execution of, practices. The rising popularity of family history as a leisure hobby is, at least in part, related to the increasing ease of access to digitized online archives, as well as to the widespread pre-existing online skills and internet familiarity developed through web-based leisure practices. The tracing of ancestors within archives also requires the execution of specific competences and skills. Frequently a time-consuming, painstaking, sometimes expensive pursuit, family historians often refer to the 'addictive' or compulsive nature of their 'hunt' for ancestors (Lambert 1996) with the hobby described as 'an infection, an obsession, a bug you catch and cannot shake off' (Nash 2002: 38). Rather obviously, practitioners take up family history to find out more about their family history. But once so engaged, for many the process of finding out becomes as significant to their experience as what they find out, and new ends are created. The effective performance of family history requires judgement, problem-solving skills and technical expertise, and as such generates 'internal goods' (rewards specific to a practice): in the acquisition of the skills and know-how necessary to conduct family history, and in the satisfactions that accompany the development of those skills, realized in its pursuit (Macintyre 1985). It is in the exercise of these skills that much of the pleasures of family history reside. But such internally generated rewards depend on family historians following the logic of the practice, which shapes the activities and information on which they place value.

Analysts identify a number of common elements in the identity-work of family history: with activities framed as a form of identification with ancestors as people; as a personal journey of self-discovery; and as a reshaping of prior understandings of belonging. It is argued here that these features of 'identity-work' emerge as a consequence of how the practice is organized, rather than primarily as the outcome of personal choice or individual creativity. This paper explores how the conventions of family history as a social practice steer the activities and accounts of family historians, and help produce these dimensions of 'identity-work'. In doing so, it explores 'identity-work' as a situational consequence of people's engagement in practices, which provide an internal logic to their actions. After reviewing research which frames the activity as a question of 'identity', the paper turns to examine family history as an archive-based hobby. Drawing on a small-scale qualitative project designed to explore the types of narrative that emerge in accounts of family history research (Bottero 2012), the paper examines the scripted 'storying' of family histories, and the role such stories perform in the display, and accounting for, family history practices. Finally, the paper explores the internal work such accounts perform, organizing the fragmentary and ambiguous information that family history research produces, in the process generating particular kinds of narrative account. The 
distinctive contribution of this paper is to use practice theory to explore questions of 'identity' in family history: with the broader implication of its argument being that we should focus less on 'identity' as an individual or group attribute or achievement, and more on how processes of 'self-understanding', 'identification and categorization' and 'commonality and connectedness' are distributed within and across collectively ordered social practices. In so arguing, the paper explores how various components of 'identity' emerge as categories of practice, grounded within material arrangements. However, whilst addressing family history as a social practice which steers practitioner behaviour, the paper retains a central focus on questions of 'identity', an issue sometimes lost sight of within versions of practice theory.

\section{Family history - 'identity' and practice}

Research into family history emphasizes its significance for processes of 'identity'. Kramer sees genealogy as a 'creative and imaginative memory and kinship practice', used to 'map affinities and connectedness, enact relatedness, and produce self-identity' giving 'selves in the present....a geographical and/or temporal "place to stand"' and constructing historical and geographical 'belonging' (2011b: 379,392). For Nash, genealogy is as activity which joins 'imaginative self-making and guarantees of truth about individual identity', entangled in 'highly personal senses of self and collective versions of ethnicity and nationhood' (Nash 2002: 28-9). Nash's work on those tracing Irish ancestry found a 'desire for connection, to match something in themselves to another place and to other people', so that 'finding out where they came from' was linked to knowing 'who they are' (2002: 37; 2008). Likewise Basu, researching 'roots tourism' to the Scottish Highlands (in the 'pilgrimages' of Australians and North-Americans to 'ancestral homelands'), found the 'sites of memory' visited were both 'sources of identity' and 'shrines of self' (2007: 219). This emphasis on questions of self-understanding in family history is unsurprising, since social memory research emphasizes the importance of biographical memory in shaping 'identity' through continuity to an imagined past (Thompson 1993: 36). Remembering the past is 'crucial for our sense of identity' (Lowenthal 1985: 197) with this 'situating of the self' occurring through 'the development of a self-narrative that starts, not at one's birth, but with one's forebears' (Lawler 2008: 42).

The appeal of genealogy is said to lie in its 'ability to both embody and individualize the past' (Nash 2003: 194), with the idiom of family connection governing genealogy making it 'easier than expected to project oneself into the historical past, to imagine oneself into the character and historic experience of one's ancestors' (Kramer 2011a: 442). Practitioners 'disseminate information about the family to interested parties' (Lambert 1996: 137), operating as 'memory workers' in which an 'important part of these memories, 
beyond the mere "facts", are the arguments and interpretations that genealogists advance in favour of their ancestors' ( Lambert 2002: 125). Such narratives are 'well-rehearsed' and 'cast in story form' (Lambert 2002: 125). In such accounts, analysts see 'the creation of "identity extensions" beyond the present - expressing responsibility for ancestral pasts and to future descendants via historical narrative' (Hackstaff 2010: 666), with 'the ultimate need... to create a larger narrative, connect with others in the past and in the present, and to find coherence in one's own life' (Yakel 2004: n.p). Family history is also a selective process, with certain ancestors or ancestral lines highlighted over others. Genealogy locates the individual in 'complex and overlapping, rather than simple, linear histories' (Nash 2002: 39) so tracing a family history entails an active process of selection, with such choices seen as particularly revealing for questions of identification, belonging and relatedness. The past is 'searched for something (someone, some group, some series of events) that confirms the searcher in his or her sense of self' (Steedman 1996: 103), with recognition key to determining what is 'made of the past' with some traits 'disowned and others embraced' as 'active identitywork in the context of kinship' (Lawler 2008: 39). The significance of dominant discourses, not only of kinship, but also of history (of diaspora, wars and industrialization, colonialism and slavery, nationality and ethnicity) in giving shape to such selections is apparent. Basu's 'roots tourists' often highlighted their Highland Scottish heritage over others, which he connects to the 'romantic image' of 'mountains and glens, misty isles and loch-side castles' (Basu 2007: 41). Genealogy also has the capacity to disrupt dominant discourses and give rise to unexpected notions of belonging (Nash 2002: 48). Nash's study of NorthAmericans tracing Irish ancestry, found genealogy could have 'unsettling results' for popular accounts of 'Irishness' (and the Irish diaspora as a response to colonial oppression), similarly, Tyler, reviewing research on oral and archival histories of slavery, notes they can reveal 'forgotten interracial European and African ancestries' (Tyler 2008: 1872).

Research on family history, then, identifies several common themes: family history as a personal journey of self-discovery; projection into the past through identification with ancestors as people; and family history as a selective and creative narrative, reshaping prior understandings of belonging, identity and self. How do these features of 'identity-work' relate to genealogy as an archive-based hobby? In what follows, I consider how family historians' storied accounts of ancestors connect to family history as a social practice with a wellestablished set of procedures and technologies. Gubrium and Holstein (2009: xv, xv-xvi) focus on the 'social life of stories', noting research can 'strip narratives of their social organization'. They emphasise the practical functions of stories, because 'storytellers not only tell stories, they do things with them' (2009: xvi). One of the things genealogists 'do' with stories of family history is to rehearse questions of identity, belonging and connection. However, such stories also perform practical 'work' in relation to the tasks of family history. Existing research has addressed many of these tasks, which I draw on in discussion. However, this paper 
places greater emphasis on the practical purposes of storying in family history, focusing particularly on how such stories (and the identity-work they entail) are steered by the tasks of genealogy, considered as a social practice.

The research on which the paper is based derives from a small-scale qualitative project exploring narratives of family history research ${ }^{1}$. During a 3-4 hour semi-structured interview, participants were asked how they had conducted their research and what they had found out using 'family tree elicitation', an extension of photo elicitation (Hirsch 1997). Interviews with participants chiefly explored their family trees and the documents relating to them, with discussion guided by the information my respondents chose to highlight. Other studies had indicated the strongly 'storied' nature of family history, so participants were asked directly about the 'sorts of stories' that had emerged during their research. During the interviews, my participants and I sifted through documents - certificates, computer print-outs, maps and photographs, letters and newspaper clippings; looked at computer or web files, clicking through the links of family tree diagrams, pulling up supporting sources, and examining the potential family connections suggested by websites. This approach was designed to explore those features my participants saw as interesting and significant, but also to explore the range of information that people might have collected as 'hinterland' to their stories. The project accessed talk about family history through a discussion elicited via the material outcomes of that practice, nonetheless, serendipitously this approach highlighted the significance of specific family history documents within people's accounts, as well as the central importance of the practical tasks, technologies and materials of archive research which had generated them.

Practice theory directs attention away from the individual (and their personal attributes and circumstances) to focus on practices as the unit of analysis. In the sociology of consumption, practice theory has been used to explore how consumption occurs as items are appropriated in the course of performing practices. This 'requires looking beyond the individual to reveal how the myriad of practices in which actors engage are collectively coordinated, ordered and performed', recasting notions of need, want and demand 'as a consequence of the "doings" (or practices) through which daily lives consist' (McMeekin and Southerton 2012: 351, 350). Instead of positing a cognitive model of the self, and a 'world peopled by very self-directing persons in serious pursuit of the coherent narrative of the self' (Warde 1994: 881), practice theory sees the social world as 'populated by diverse social practices which are carried by agents' (Reckwitz 2002: 256). Family historians undoubtedly engage in various activities which can be characterised as 'identity-work', but I argue here that these meanings and purposes are better understood not as the attributes of individual family historians and their social or psychosocial circumstances, but rather as 'elements and qualities of a practice in which the single individual participates' (Reckwitz 2002: 250). Shifting the analytic lens away from 
family history as an exercise in self-making, towards family history as a practice (that is, an archive-based hobby organized around concrete tasks of collecting and processing historical records), is an attempt to ground questions of 'identity' in the analysis of shared material arrangements and practices, and to avoid the methodological individualism and voluntarism that sometimes besets accounts of lifestyle choices and activities. Indeed, the 'practice turn' partly reflects a rejection of those versions of social theory which assert 'the predominance of a particular social psychology of the self, a self which is defined by the labour of creating and sustaining a "self-identity"' (Warde 1994: 877). Nonetheless, engagement in practices has significant consequences for people's 'identity' and in casting people as the 'carriers' of practices, there is a potential danger of effacing the individual and of losing sight of 'identity' altogether. This paper attempts to locate questions of 'identity' within social practice theory, by exploring how 'identity' and individual 'identity-work' are formed within the practice of family history.

What is it about the features of family history as a practice that steer the 'identity-work' that others have identified? Leaving to one side explicit questions of identification and heritage, family history also operates within a discourse of expertise, with rules about the correct (and incorrect) way to conduct ancestral searches. Requiring effort, skill and enthusiasm, it produces a detailed but uneven body of documentary information. As a routine feature, family historians sift through a mass of archive records to generate a smaller set of fragmentary, ambiguous and disparate archive evidence about kin. Whilst usually identifying scores of connections, for many ancestors little or no information is found. The typical results of a search produce perhaps a handful of ancestors, scattered haphazardly about a family tree, for whom detailed (or 'rich') archive information can be found, with the most detailed information generally held on ancestors who live on in family memories. For large numbers of ancestors, identified chiefly through the archive, only limited information (a date or place of a birth, death or marriage, sometimes an occupation) is discovered. The intractable nature of genealogical evidence is part of the appeal, with the dogged hunt for information one of the chief pleasures of the practice. After all family history as a hobby is a form of 'serious leisure' (Stebbins 1992) in which people invest effort in dogged pursuits as part of the pleasures of the practice. As such, it shares features with other hobbies (such as collecting memorabilia) which are less straightforwardly exercises in 'self-making'. But given the uncertain and incomplete nature of the evidence that family history produces, storied accounts perform practical organising and presentational 'work' in the conduct of the hobby, which operate in two interrelated kinds of 'scripted' accounts: in stories of ancestors as people, and in stories of the research process which has recovered them. To further explore this we must examine the procedures by which family historians acquire genealogical information. 


\section{Telling a good story: recovering ancestors as people}

Family historians frequently frame their accounts as telling a 'good story' about ancestors, recovered from the dusty past as flesh-and-blood individuals, with stories often having a 'polished' feel (Lambert 1996, 2002; Yakel and Torres 2007). Clearly an extension of those 'family stories' which are part of the ordinary currency of family relations (Gillis 1996; Smart 2007), such accounts of ancestors as acts of recovery also operate as stories of research success, and of the family historian's accomplishments in the archive. They serve as evidence of the family historian's activities and of what is valued in the activity, reflecting the 'internal goods' of family history. Internal goods arise from the possession of the skills specific to a practice and the pleasures that accompany the development of those skills, realised by practitioners 'in the course of trying to achieve those standards of excellence' definitive of a practice (Maclntyre 1985: 286). The attainment of family history skills and the pleasures of their execution - the internal goods of family history-are ends pursued for their own sake and an important feature in the accounts of family historians. Research on family history has concluded the practice demonstrates the 'creative and negotiated dimension of kinship' in which 'people take as much pleasure in making themselves connected and rooted, as in being rooted and connected' (Kramer 2011b: 393). But a key pleasure here rests in the successful performance (and display) of the research, with practitioners gaining a 'major source of personal satisfaction' in 'learning research skills, the challenge of problem-solving, the thrill of discovery, [and] associated feelings of competence' (Lambert 1996: 136). That accounts so often take a particular form - recovering 'interesting' ancestors - is related to these internal goods. Certain kinds of information and processes become highlighted, so that 'telling a good story' and 'personifying the past' have a practical significance as features of the successful conduct of family history.

Instructed to start from what is 'known' in the family, family historians are warned to be sceptical about the 'facts' of family memory, and wary of the errors that creep into archive sources. The start of the research is generally a web search on the name of an ancestor, often generating many potential matches, which must be corroborated by age or other particulars. Such records throw up information about further connections which are traced in turn:

You look at a census certificate and you try to extract as much information as you can, like finding out where an ancestor was born, which is brilliant because you can suddenly leap back and across the county and you find out a little bit more about him and you've got a line to track. Then you see other people in the household and you find out a bit more about them so that a preconception is destroyed, you think of somebody as coming from Yorkshire and suddenly found out she was born in Cheshire. You know so, Aha, then you you've then got a solid lead to find that person. (William²) 
I started to look up the census and it all sort of gelled in then, the children's name matched, the ages matched, and you think, well it's got to be... (Jerry ${ }^{3}$ )

This search activity, an absorbing process of 'messing around' in archives and making sense of old records, is one of the chief pleasures of the practice. Family historians speak not just of the addictive nature of their pursuit, but also of their enjoyment of the 'hunt' (Lambert 2002: 126) which is likened to detective-work, solving a crossword or completing a jigsaw puzzle. But whilst 'empiricist' in orientation, the practice of family history requires an active process of interpretation, reflected not only in family historians' storying of accounts, but also in their explicit recognition of such narratives as interpretations of research. As Lambert notes 'The process of "discovering" a family's past includes a significant degree of invention', so that 'confronted with a few "facts", respondents were invited to "complete" the stories in their imagination' (Lambert 1996 138; 2002: 123). The fragmentary nature of archive records requires this active 'storying' to make sense of ancestors' lives:

So they've migrated south when they were tenant farmers. Why? I've got a theory but - that particular John there. Flag him up and see his details. He, I think, appears in Manchester running or owning a pub. Now, perhaps - this is one of the bits I want to check - if he did it's possible he met his wife there, Anna, who comes from the Chorlton area. She was working, they got hitched and decided to set up house in the south of Manchester. He was a farmer perhaps running a pub as a job to earn money, anything. (William)

You're making up stories aren't you? You're just filling, filling in the gaps in the knowledge with the idea about who these people were. $\left(\mathrm{Carol}^{4}\right)$

Studies of oral history and autobiography identify 'conventional forms' or scripted sub-genres in accounts (including the 'legacy to posterity', the 'picaresque adventure', the 'success story', and the 'conversion experience'), often employing traditional literary themes (such as the event that 'changed everything' or 'the person who persevered') to make sense of events (Chamberlain and Thompson 1998: 4). Similar scripted themes are found not only in family historians' accounts of ancestors but also of the conduct of family history, which is framed as uncovering secrets, discovering the unsuspected, recovering forgotten lives. The puncturing of myth is, of course, a standard trope of historical narrative (Samuel and Thompson 1990), here linked to the rules of procedure, evidence and interpretation which constitute family history. Stories of ancestors build in the research work, framed as a hunt through archives, requiring detective-work and problem-solving skills. But in seeking to personify the past and story ancestors' lives, family historians must work with the contingent, fragmentary nature of archive records.

The richest personal detail is generally available on ancestors remembered in family stories, with archive research framed as throwing new light on 'known' kin. Family secrets are frequently hinted at within 
families (Smart 2011), so 'half-known' family stories (the bigamous marriage, the 'hushed-up' adoption) can be revealed (or confirmed) through archives, with family history reconfiguring family memory. For more remote ancestors identified only through archives, the records typically available (kinship registrations, household residence, carceral institutionalization) mean that 'interesting' stories are often 'sexual stories' (illegitimacy, very large families, bigamy, incest etc) or accounts of the 'picaresque', hardship and the hand of fate (criminal histories, poverty, sudden deaths). By the nature of what survives in genealogical archives, some ancestor's lives are more 'storyable' than others, so questions of selection (and identification) are constrained by the internal goods of the practice. The attempt to recover ancestors as people means 'family history seeks to enrich pedigrees with biographical, historical and other contextual information situating ancestors in their time and place' (Lambert 1996: 166). But this depends on what can be found in the archive, and certain records provide better 'material'. Take Sally's presentation of her great-grandfather's life as a 'quite exciting running away to sea story':

He disappears off censuses, and we can't find him for about 17 years. [...] But we know he ran away to sea. From what I did find out from my Great-Aunt he just used to appear and reappear quite randomly, and leave them quite short of money. They lived in a tenement in Glasgow. And he was a bit of a drinker. And he used to randomly come back and bring some very exotic gift like a monkey to a Glasgow tenement, which of course died of the cold! [...] I think he never really mentioned his life to his kids because my Dad was convinced that they were Scottish going all the way back ... And the real clincher for my Dad was finding out that he was born in a street half a mile away, in Bolton! My Dad was gutted! I mean that was the irony! He was born in his grandparents' house, which was in X Street in Bolton, which is near B\&Q. I said, "You've come as far as B\&Q, Dad." And he was like, "No!" He was just like, "You're kidding me."... I said, "Well at least you don't have to wear the horrid kilt!" (Sally $\left.{ }^{5}\right)$

Sally's account is of family history research reconfiguring her family's memories of a 'colourful' ancestor. The discovery process and surprising results are now themselves a well-polished family anecdote. Sally explicitly identified with her great-grandfather as someone who had done 'something different', which she related to her own situation, as the only member of her family to have moved away and gone to university. But Sally's focus on this ancestor as someone who had done 'something different' was also a question of how the facts of his life meant more of a story could be constructed around him as a 'character':

You're never looking for the boring stuff. My Dad's family, once you go back from the quite exciting running away to sea story, you get a lot of farmers who have the same name. And it's great to know that your family can go that far back and that you're related to most of Rochdale, by the looks of it. But- you're really looking for stories of people that did something different...it gives you more clues about their life really... (Sally)

My respondents placed most value on those records which offered vivid snap-shots of past lives. Letters and diaries offer rich 'personal' information, but are relatively rare. Newspaper, legal, military and school 
records, however, can provide picturesque cameos: such as the newspaper reports of the shipwrecked mariner who 'escaped a watery grave' only to 'die on land...the greater portion of his body destroyed by crows'; the dead child, body-snatched from her grave, whose corpse was found in a box by suspicious staff at a hotel; or the bride 'dressed gorgeously in a net dress embroidered in silver' whose wedding was attended by F. Scott Fitzgerald and whose cake 'weighed 80 pounds'. Other records offered startling glimpses of incidents in ancestors' lives, their actions frozen in the archive, as in the court documents of an ancestor accused of attempted rape of whom it was alleged that he 'got her down on the floor but had not carnal knowledge of her person' and 'afterwards pulled out his pocket book with several ten pound notes in it and offered her any money to let him have his will of her'. Such ancestors leapt from the archive as people about whom there were stories to tell - and demonstrated the success of the research as an act of recovery. But a family history generally contains relatively few instances of such vividly realised ancestors:

Just because they're old doesn't necessarily make them interesting does it? [...]You've got to get a story behind them, and the further back you go the harder it is to create a story about somebody. (Derek ${ }^{6}$ )

Lambert's research into those researching convict ancestors in Australia noted the 'competitive nature of the search' for convicts - seen as 'collectibles' - with convict ancestors providing greater 'narrative potential' (Lambert 2002: 119-120). The appeal of convict ancestors as 'interesting' stories (Lambert 2002: 120) is linked back to the present day, as genealogists write themselves and their family into their ancestral narrative:

my respondents told me at some length about the ways in which the [convict] stain had played itself out in their living and ancestral families. They speculated about who in their families might have known about their convict origins and how this knowledge might have been suppressed or "lost" to family memory. (Lambert 2002: 116)

Similar types of 'recovery' stories emerge even when less evidence is available, with the effort and skill required to dig information out showcased in accounts closely interweaving stories of ancestors with stories of grappling with information in the archive:

it's quite difficult to piece it all together and make sense of it. But the sense l've made of it is that she left her first husband, for whatever reason, ended up in Bury giving birth to my grandmother. A few years later met a man called James who, himself, was already married. I haven't been able to find a death certificate for his wife, his first wife. I don't think he actually married my great-grandmother, I don't think they actually got married. I haven't found marriage certificate, but they lived together as man and wife [...] I was drip feeding it to my mum as I came across the information, and she...found it very difficult to accept that that could have been the case, and was sort of saying well you know, I'm sure they wouldn't have lived together if they hadn't have been married! (Pauline ${ }^{7}$ ) 
In 'showing their work' in this fashion, family historians demonstrate their technical accomplishment and the value they place on it. The narrative of the research process is a central framing device: an 'interesting story' in itself, as family historians 'write themselves in' to the narrative. The potential significance of this for processes of identification and self-understanding is apparent. It also places the active, practical performance of the family historian at the heart of accounts. But if family historians' work in the archive serves only to confirm that which is already known, then in some sense their work is a failure or, at least, rendered less interesting. So the framing of 'good stories' as surprising acts of recovery (and so family history as reshaping prior understandings of belonging) is a feature of successful practice.

In generating such accounts, family historians trace the continuing influence of the past in the present. They also justify their own activity of tracing distant connections and arcane historical information in terms of its contemporary relevance and personal significance. Family history is framed as the 'democratic recovery' of the dead, a process of 'restoring individual ancestors to living memory, without regard to rank' (Lambert 2002: 112) in which genealogists 'reconstruct missing archives and absent records in the attempt to restore the transmission of memory between generations' (Kramer 2011a: 431). Such powerful framing devices of family history as the recovery of the dead are a form of projection into (and identification with) the past, but they also serve as a rationale or 'vocabulary of motive' (Mills 1940), in which family historians frame (and organize) their potentially recondite hobby. One role of hobbies lies in providing a sense of accomplishment as 'Learning and playing by the rules of the game for making a good collection help the collector gain a sense of mastery and competence' (Belk 1995: 150). The desire to share their enthusiasm is a feature of hobbyists' accounts, but there is also an awareness of the dangers of becoming a 'hobby bore'. Kramer (2011b) notes family history is sometimes seen as dull, or lacking contemporary relevance by those who do not pursue it, and family members can feel resentment about the energies genealogist devote to the distant dead. The very idiom of kinship which facilitates the family historian's identification with people in the past may make the subject less accessible for others (much like the dubious interest of other people's holiday pictures). My respondents frequently offered 'health warnings', suggesting their research was really only of interest to immediate family, swiftly qualified by reference to those family members who took no interest in it.

I've made a little start on one [a family history] for my wife. [And she's interested in the family history?] Not particularly. I don't get any impression that she is, no. I sort of got the feeling I might complete it and then it's there for Jim [son] if ever he should want it, really. I don't know. [And is he interested?] No. [Both laugh] $\left(\mathrm{Ken}^{8}\right)$

Family history as a hobby is not dissimilar to 'collecting hobbies' (such as collecting stamps or memorabilia), with a similar accounting for practices. Collecting is not a guilt free activity (it may be seen as esoteric, selfindulgent, or as taking time and money away from family) and hobbyists often feel prompted to justify their 
activity to others (Belk 1995). With striking similarities to family historians, collectors form accounts which justify their activities, stressing the addictive nature of their hobby, and emphasizing their role as saviour of lost, neglected or endangered objects, so that the:

collecting even of such mundane objects as Mickey Mouse characters ... make collectors feel that they are part of a great tradition and are contributing in a small way to either art or science. (Belk 1995: 76)

Constructing family history as the rediscovery of ordinary lives universalises and provides relevance for the pursuit:

You've got to stop me in a moment because I will wander off. I mean I have people who pretend they're lamp posts when we're in the street because if they stand still long enough I won't see them and I won't tell them my latest research! But having said that.....right! [...] I suppose it was all about bringing them back to life, do you know what I mean? Because as we both know, the majority of people in history are just totally and utterly ignored. I mean my great grandmother I think, her whole history is summed up by something like seven or eight official documents. And that's it. (James)

So far I have suggested that the typical framing of accounts of ancestors' lives reflects the internal goods and conventions of the practice, providing proof of expertise in stories of the successful recovery and transformation of knowledge that careful research in archives has achieved. But such narratives also perform valuable work within the practice of the research itself: operating as an organizing device helping to connect incomplete information, whilst retaining the inherently ambiguous nature of that information. Work in genealogical archives routinely generates a mass of partial and ambiguous material, and stories of both ancestors and of the research process work to fill in the gaps in this material, coordinating information into plausible scenarios and allowing family historians to weigh up alternative explanations. The narrative of the research process as a journey of (re)discovery, linking past to present, is a key framing device helping to connect fragmentary or ambiguous archive records, which again places the skilled interpretative work of the family historian - and their sense of personal engagement with ancestors - at the heart of accounts.

Family history research typically generates miscellaneous information about ancestors, whilst its procedural norms emphasize caution towards the uncertain nature of the evidence found in archives. As analysts have noted, these procedures both require, but also constrain the storying of ancestors, with discoveries in the archive providing the capacity to disrupt dominant discourses and cherished assumptions in surprising and unexpected ways. As Nash indicates, the 'demand that searchers start with themselves and work backwards, can challenge some of the neatness of a kind of idealised Irish identity in which a single Irish line is the only one that matters' ( Nash 2002: 38). There are limits to the malleability of interpretations of history (Zerubavel 1995), since norms (of credible sources etc.) govern legitimate debate of the past (Appadurai 
1981), and family history has clear conventions about this. Family historians refer frequently to the sifting process, to their own mistakes in the search, to the mistakes of others, and to the dubious nature of some archive records. Sharply aware of the potential to 'go wrong', they routinely rehearse issues of accuracy and interpretation, stressing that what they uncover is provisional or limited:

I wanted some drama in the family and I found another Galloway and there was like some criminal records, you think, I shouldn't really be looking at this, but it's really good! And he was deported to New South Wales and it was his wife's application for him to go for murder. And I was like, yes! So I tried my best to make him fit. I wanted, but no. It was more like a round peg in a square hole... I was like adamant, let's get this criminal in the family! Because it is easy when you find somebody to go, yes, that's them. And then you think, there's no way those dates match... (Jacky ${ }^{9}$ )

it's like looking through a dirty window, you know you can see some of what's going on but you can't get it all. $\left(\right.$ James $^{10}$ )

Narrative always interprets events, shaping their meaning (Polkinghorne 1995; Toolan 1988), but family historians explicitly flag their stories as interpretations, reflecting the caution that 'good practice' requires. Take, for example, Carol's account of her female ancestor, Annie. In a process described as a 'detective story', Carol's reconstruction of Annie's circumstances from census and birth registers indicated that she had given birth to several illegitimate children, all subsequently adopted. Carol's tentative conclusion about Annie's story also acknowledged other possible interpretations:

she was pregnant, or getting pregnant while she was as a housekeeper in that household ... so the fact that she had gone to York had this child and then gone back or, gone to work as a housekeeper for this man and then was working subsequently as a housekeeper for this man ... I thought Joseph the man she was working for, was probably the father of these. Now whether it was a consensual relationship or not I don't know. You know she was his servant and he had been married and had been widowed twice, and he had six sons, and so, you know I've been looking into his tree, cause he is probably the unknown father in all this. [...] I would never know whether this was a consensual thing or whether he was talking advantage of her, but the fact that she sort of kept going back sort of suggests that it was a relationship that they were having in secret. (Carol)

Such stories, framed according to a 'dual standard of "Did it happen that way?" and "Could it have happened that way?"' emerge when people must deal with ambiguous information (Bennett 2001: 97). Carol's account organizes and interprets fragmentary material whilst retaining a sense of its limitations and uncertainties. In doing so, Carol writes herself - and her sense of connection to Annie - into the family history. The act of making connections is also framed as one of being connected, as Carol emphasises not only her own role in recovering the information, but also in giving testimony for Annie. 
it doesn't tell you much, does it, about who, you know, who was with who? I think I need the narrative, especially with this story because it is a story, it is a kind of, you know, piecing together of these bits of information kind of made a story about, you know - I need to see that she kept going. (Carol)

The conduct of family history is often (though it should be noted not always) framed within explicit discourses of the search for personal identity. Carol's narrative is not only of a journey of discovery in the archive but also of a journey of self-discovery, linking the discovery of Annie's lover to Carol's own sense of 'self':

\footnotetext{
'Cause some of my genetic makeup comes from him and I've got this blank in my tree where, you know, I have no definite idea of who, what, where that goes to you know, and so it's just that really it's just my desire for completeness [...]I'm interested in you know, what makes me up. (Carol)
}

The idea that family history serves to fill in the gaps in our knowledge of what 'makes us up' is a common trope. However, in such accounts we can also see discourses of 'self' and 'identity' performing practical organizing work and being used to fill in the gaps in family history. Carol's family history research had generated not only her 'detective story' of Annie and Joseph, but also several stories of 'shot-gun weddings' and 'doing a bunk'; as well as stories of her independent great-grandmother, employed into her 80s (though lying about her age) and inexplicably fluent in French; of a wealthy provisions' merchant, 'importer of Danish Hams' who had swiftly remarried his dead wife's sister; the gamekeeper's son privately educated at a Catholic boarding school; an innkeeper living on a bleak and isolated moor; the ironstone miner killed in a rock fall; and the couple who met at Blackpool on a Wakes Week. The key theme linking these disparate narrative elements was $\mathrm{Carol}$ and her connection to these people, discovered through her research. Kinship connections are in one sense somewhat arbitrary links, so the process of tracing a family tree often produces miscellaneous information about a heterogeneous collection of individuals. Often widely separated in space as well as time, many ancestors' only connection to each other is through their kinship to a distant descendant - the family historian. All family trees, after all, converge on 'ego'. In this context, just as stories of the research process serve an integrating function linking fragmentary evidence, so accounts of the research process as journey of self-discovery help family historians make connections between an often disparate and incomplete set of ancestral stories.

Key features of 'identity-work' in family history - such as the construction of research as a journey of discovery in which the family historian takes centre stage, and the personification of and identification with particular ancestors - emerge as a consequence of the procedures and internal goods of family history as a practice. Given the uncertain and incomplete nature of the evidence that family history produces, storied 
accounts of the research perform practical organising and presentational 'work' in the conduct of the hobby. It has been argued that the pursuit of family history 'compels everyday personal engagement with the meaning and legacy of inheritance for collective and individual identification and identity' (Kramer 2011b: 379). Certainly the procedures of family history and the internal goods of the practice compel family historians to place themselves at the centre of their accounts of ancestors and of their family tree. Narratives of the research process operate as a central framing device in which family historians 'write themselves in' to the story, with past and present linked as a journey of discovery into the past. And in the process, discourses of 'identity' - as a personal journey of self-discovery - often operate as powerful organizing script, showcasing the activities and expertise of the family historian, whilst also connecting the rather disparate pieces of information that the practice generates. In this way, talk of self and identity can serve as a strategic resource within the conduct of family history: a narrative tool working to connect and account for the practical tasks of the activity.

\section{Conclusion}

This paper has explored family history as a social practice, examining accounts of family history (and the 'identity-work' they entail) in terms of such stories' practical orientation - fulfilling specific tasks in the practice of family history, and reflecting its internal goods and values. Whatever the reasons people take up family history, once recruited into the practice strong procedural conventions shape new ends, and steer activities and accounts. An absorbing leisure hobby of 'messing around' in archives, the enjoyment of the pursuit consists as much in the 'thrill of the chase' as in what is actually discovered. Family history is a pleasurable but painstaking, sometimes esoteric hobby, and in storying their research genealogists showcase their expertise, and provide an accounting for the practice. Family historians routinely sift a mass of records to generate a smaller set of fragmentary, ambiguous archive evidence about kin, and for many ancestors little information is found. The procedural, problem-solving elements of the practice provide challenge and a sense of accomplishment, but also a strong narrative frame for accounts. The emphasis on recovering ancestors as flesh-and-blood people from potentially 'dry' archive records demonstrates the family historian's success in their pursuit, with accounts framed with an emphasis on the research, in an organizing device framing family history as a process of surprise and recovery, linking past and present and placing the active role of the family historian at the centre of narratives.

Whether or not family history helps genealogists find greater coherence in their wider life or sense of self, it certainly seems that the performance of family history, as well as the information it uncovers, does provide a 
'resource for identity-work' (Kramer 2011b: 391) albeit in a number of distinct ways. For some genealogists, family history is part of a reworked account of personal connection or belonging. Their investment and pleasure in the skilled accomplishment of tasks is clearly another consequential aspect of the practice for family historians' sense of 'self'. For Nash (2002: 49), the study of genealogy provides 'a way of beginning the task of understanding the complexities of subjectivity and social location, and of rethinking identity as neither eternally fixed and essential, nor endlessly fluid and freely self-fashioned, an always incomplete inventory of the self'. Here, I have offered an alternative lens on family history: seeing it as collectively ordered social practice, in which features of 'identity-work' emerge as a consequence of how the practice is organized, rather than as the outcome of personal choice, self-making or individual creativity per se. Some components of identity-work in family history are pragmatic features situationally evoked as family historians pursue particular tasks and engagements in their research. And just as the forms of connection and identification produced within family history reflect the internal logic of the practice and its constructions of value, so too discourses of 'self' and 'identity' also perform a utilitarian function as organizing and accounting devices within the practice. If family history, and the information it uncovers about individual ancestors serve as a resource for 'identity-work', then so too discourses of self and 'identity' serve as a strategic resource and presentational device within 'family history work'. This is not to deny the potential significance of these different elements for 'identity', but rather to suggest they be viewed as contextual, pragmatic and strategic features of task-based practices. If family history does indeed help us better understand questions of subjectivity, self and identity, I would suggest that it is by demonstrating how the various components of 'identity' are carried within, and steered by, shared social practices, with 'identity' and 'self' emerging as categories of practice, shaped pragmatically for particular uses.

If we see 'identity' as something produced when we are engaged in doing other things, not itself a practice but rather a moment in many practices, then we must examine how the practical organisation of 'doing other things' helps produce 'identity' in particular ways. Schatzki (2011: 1449-1450) notes that 'talk of practices signals the conviction that certain phenomena that previously had not been construed either as forms of, or as rooted in, human activity, are best theorised thus' and gives the example of 'identity' as an example of a phenomenon rooted in practice. However, by framing people as the 'carriers' of practices and focusing on practices as the core unit of analysis, there is sometimes a danger of practice theory obscuring questions of the individual and their 'identity'. Here I have looked at the practical organization of different components of 'identity-work' within a particular social practice to demonstrate that we can ground understandings of 'identity' within the material arrangements of social practices, without losing sight of the significance of 'identity-work' to such arrangements. There are broader implications of this analysis. For whilst it is important to see the elements of 'identity-work' as work on 'identity' (in the sense of helping to 
furnish a sense of 'self' or biographical coherence) they must also be considered in terms of how they perform practical, utilitarian 'work' within other more mundane pursuits and engagements, and take their particular shape accordingly. This paper has utilised a disaggregated notion of 'identity' to suggest that the elements of 'identity-work' discussed here emerge as a situated consequence of people's engagement in specific tasks within practices, which provide an internal logic for their actions and discourses. A further implication of this is that rather different discourses of 'identity' and forms of 'identity-work' may emerge for other practices and pragmatic purposes. Within practice theory, as there are 'diverse social practices and as every agent carries out a multitude of different social practices' the individual must be seen as 'the unique crossing point of practices' (Reckwitz 2002: 256). A practice-based approach, then, 'presents the individual as the intersection of practices' (Warde 2005: 351). So it is hard, for example, to assess the broader significance of the 'identity-work' produced through family history without some sense of how it fits within the wider practices and engagements of those who engage in family history as a leisure practice. It has long been noted that people order the events of their lives in narrative to gain self-understanding and to have explanatory accounts to offer others - what Crites (1971) called the 'autobiographical imperative'. But whilst lives and selves are in part narrative constructions, made coherent through the 'biographical work' that links events into life (and family) histories, they are also 'locally informed and organized', that is, grounded in concrete, material situations, and produced out of the ordinary procedures, tasks and local requirements of practical reasoning (Gubrium and Holstein 1994). All of which should alert us to how the various components of 'identity' emerge as categories of practice shaped within and for use, as well as to the strategic and situational nature of rhetorics of the 'self'.

\section{Acknowledgements}

The study referred to in this paper was funded by the ESRC Centre for Research on Socio-Cultural Change (CRESC) and the Morgan Centre for the Study of Everyday Life. The author gratefully acknowledges this invaluable assistance. I am also grateful for the very helpful comments and advice on this paper offered by Brian Heaphy, Dale Southerton and the editors and anonymous referees of the BJS.

\section{Bibliography}

Appadurai, A. 1981 'The Past as a Scarce Resource', Man (N.S.) 16: 201-19

Basu, P. 2007 Highland Homecomings: Genealogy and Heritage-Tourism in the Scottish Diaspora, Routledge. Belk, R. 1995 Collecting in a Consumer Society, Routledge.

Bennett, W. 2001 'Storytelling in Criminal Trials: A Model of Social Judgement' in Hinchman, L. P., and Hinchman, S. K. (eds) Memory, Identity, Community, SUNY Press.

Bottero, W. 2010 'Intersubjectivity and Bourdieusian Approaches to "Identity"', Cultural Sociology, 4 (1): 322.

Bottero, W. 2012 'Who Do You Think They Were? How Family Historians Make Sense of Social Position and Inequality in the Past', British Journal of Sociology, 63(1): 54-74. 
Bottero, W. and Irwin, S. 2003 'Locating Difference: Class, 'Race' and Gender and the Shaping of Social Inequalities', The Sociological Review, 51 (4): 463-483.

Brubaker, R. 2004 Ethnicity Without Groups, Harvard University Press.

Carsten, J. (ed.) 2000 'Introduction: Cultures of Relatedness', in J. Carsten (ed.) Cultures of Relatedness, CUP. Chamberlain, M., and Thompson, P. (1998) Narrative and Genre, London: Routledge.

Crites, S. (1971) 'The Narrative Quality of Experience', Journal of the American Academy of Religion, 39(3): 391-411

Erben, M. 1991 'Genealogy and Sociology', Sociology 25(2): 275-92.

Franklin, S. and McKinnon, S. 2001 'Relative Values: Reconfiguring Kinship Studies', in S. Franklin and S. McKinnon (eds) Relative Values: Reconfiguring Kinship Studies, Duke University Press.

Gillis, J. (1996) A World of their Own Making: Myth, Ritual, and the Quest for Family Values, Cambridge, Mass.: Harvard University Press.

Gubrium, J., and Holstein, J. 1994 'Grounding the Postmodern Self', The Sociological Quarterly, 35(4): 685703.

Gubrium, J., and Holstein, J. 2009 Analyzing Narrative Reality, London: Sage.

Hackstaff, K. 2010 'Family Genealogy', Sociology Compass, 4(8): 658-72.

Hall, S. 1990 'Cultural Identity and Diaspora', in J. Rutherford (ed.) Identity, Lawrence and Wishart.

Hirsch, M. 1997 Family Frames, Harvard University Press.

Huyssen, A. 1995 Twilight Memories, London: Routledge.

Kramer, A. 2011a 'Mediat[is]ing Memory: History, Affect and Identity in "Who Do You Think You Are?"'

European Journal of Cultural Studies 14(3): 428-45.

Kramer, A. 2011b 'Kinship, Affinity and Connectedness: Exploring the Role of Genealogy in Personal Lives', Sociology, 45(3)379-95.

Lawler, S. 2008 Identity, Cambridge: Polity.

Lambert, R. 1996 'The Family Historian and Temporal Orientations Towards the Ancestral Past', Time and Society, 5(2): 115-43.

Lambert, R. 2002 'Reclaiming the Ancestral Past: Narrative, Rhetoric and the "Convict Stain"', Journal of Sociology, 38(2): 111-27

Lowenthal, D. 1985 The Past is a Foreign Country, Cambridge: Cambridge University Press

Macintyre, A. 1985 After Virtue (2nd ed.), Notre Dame: University of Notre Dame Press.

Mason, J. 2008 'Tangible Affinities and the Real Life Fascination of Kinship', Sociology 42(1): 29-45.

McMeekin, A. and Southerton, D. 2012 'Sustainability transitions and final consumption: practices and socio-technical systems', Technology Analysis \& Strategic Management 24(4): 345-361.

Mills, C. W. 1940 'Situated Actions and The narrative quality of experience Vocabularies of Motive'

American Sociological Review, 5(6): 904-913.

Nash, C. 2002 'Genealogical Identities' Environment and Planning D 20(1): 27-52

Nash, C. 2003 “"They're Family!” Cultural Geographies of Relatedness in Popular Genealogy' in S. Ahmed, A. Fortier and M. Sheller (eds) Uprootings/Regroundings, Berg.

Nash, C. 2008 Of Irish Descent: Origin Stories, Genealogy, and The Politics of Belonging, Syracuse University Press.

Polkinghorne, D. 1995 'Narrative Configuration in Qualitative Analysis', Qualitative Studies in Education, 8(1): 5-23.

Reckwitz, A. 2002 'Toward a Theory of Social Practice', European Journal of Social Theory, 5(2): 243-263.

Samuel, R., and Thompson, P. 1990 The Myths We Live By, London: Routledge.

Schatzki , T. 2011 'Theories of Practice' in D. Southerton (ed.) Encyclopedia of Consumer Culture, London: Sage.

Shove, E. and Pantzar, M. 2005 'Consumers, Producers and Practices: Understanding the invention and reinvention of Nordic walking' Journal of Consumer Culture 5(1): 43-64.

Shove, E., Pantzar, M. and Watson, M. 2012 The Dynamics of Social Practice, London: Sage.

Smart, C. 2011 'Families, Secrets and Memories', Sociology 45(4): 539-53. 
Steedman, C. 1996 'About Ends: On the Way in Which the End is Different from an Ending', History of the Human Sciences 9(4): 99-114.

Stebbins, R. 1992 Amateurs, Professionals, and Serious Leisure, Montreal: McGill-Queen's University Press. Strathern, M. 1995 'Nostalgia and the New Genetics', in D. Battaglia (ed.) Rhetorics of Self-Making, University of California Press.

Thompson, P. 1993/2005 'Family Myths, Models and Denials in the Shaping of Individual Life Paths' in D. Bertaux and P. Thompson (eds) Between Generations $2^{\text {nd }}$ edition, OUP.

Toolan, M. (1988) Narrative: A Critical Linguistic Introduction. London: Routledge.

Tyler, K. 2005 'The Genealogical Imagination: The Inheritance of Interracial Identities' The Sociological Review, 476-94.

Tyler, K. 2008 'Ethnographic Approaches to Race, Genetics and Genealogy', Sociology Compass 2(6): 186077.

Warde, A. 1994 'Consumption, Identity-Formation and Uncertainty' Sociology 28(4): 877-898.

Warde, A. 2004 Theories of Practice as an Approach to Consumption, Working Paper 6, ESRC Cultures of Consumption Programme, London.

Warde, A. 2005 'Consumption and Theories of Practice', Journal of Consumer Culture, 5(2): 131-153.

Yakel, E. 2004 'Seeking Information, Seeking Connections, Seeking Meaning: Genealogists and Family Historians', Information Research 10(1) http://informationr.net/ir/10-1/paper205.html <accessed 04/05/2012>

Yakel, E., and Torres, D. 2007 'Genealogists as a "Community of Records"', American Archivist, 70(1): 93113.

Zerubavel, E. 1995 'Social Memories', Qualitative Sociology 19(3): 283-99.

\section{Notes}

${ }^{1}$ Twenty-one family historians were interviewed in an in-depth qualitative interview study based in Northern England. The sample included historians based in the North England researching ancestors from elsewhere (including outside the UK), and historians researching ancestors from northern England who themselves lived elsewhere. All, bar one, resided in the UK. Participants were recruited through the leafleting of libraries and Family Record Centres, news-group and message-board adverts to websites of Family and Local History Societies, and by snowball sampling. The aim was to construct a sample of people engaging in family history in a range of ways (members of history groups as well those pursuing solitary webbased research). The achieved sample is not representative of any larger population, and is predominantly 'middle class', white, older and well-educated in its characteristics. The sample comprised 13 men and 8 women. All bar one were 'white'. Their ages ranged from 25 to 79, with a mean age of 57. Of the 21, 4 were in NS-SEC 'routine or manual' class occupations', 1 in an 'intermediate class' occupation and 16 were in 'managerial or professional' class occupations, with these latter considerably higher in cultural rather than economic capital, with a preponderance of workers in education.

${ }^{2}$ Retired construction engineer, 66

${ }^{3}$ Business development manager, 59

${ }^{4}$ University researcher, 42

${ }^{5}$ Administrative assistant, 31

${ }^{6}$ Retired head teacher, 59

${ }^{7}$ Housewife, formerly personnel officer, 51

${ }^{8}$ Teacher, 54 
${ }^{9}$ Enterprise co-ordinator, 29

${ }^{10}$ Retired teacher, 60 